\title{
Evaluasi Kualitas Pembelajaran Online Selama Pandemi Covid-19: Studi Kasus di Fakultas Teknik, Universitas Katolik Darma Cendika
}

\author{
Desrina Yusi Irawati ${ }^{1}$, Jonatan ${ }^{2}$ \\ 1,2) Fakultas Teknik, Program Studi Teknik Industri, Universitas Katolik Darma Cendika \\ JI. Dr. Ir. H. Soekarno 201, Surabaya 60117 \\ Email: desrina.yusi@gmail.com, nathanjo2001@gmail.com
}

\begin{abstract}
The home-based learning strategy is a useful control measure to decrease the spread of COVID-19 among students. A sudden alteration of offline learning to online learning impacted the effectiveness of learning activities. During the COVID-19 pandemic, the Faculty of Engineering, Darma Cendika Catholic University needed to assess the level of student satisfaction of online-based learning so that the quality of service was maintained. The purpose of this study was to measure the level of student satisfaction during online-based learning during the COVID-19 pandemic using the Service Quality (Servqual) and Importance Performance Analysis (IPA) methods. Servqual and IPA are methods for measuring the level of satisfaction and quality of service. The result of Servqual shows all the measurements of 17 attributes have negative gap value. This shows that there is a difference between students perception and expectation of online-based learning. The Matrix of IPA indicates the priority of improvement of online-based learning that encompasses the lecturers consistency in providing a good lecture, the capability of using learning platform, the prompt and efficient response to students needs in online-based learning, the encouragement of students motivation throughout the learning process, and the understanding of students impediments during the process of online-based learning.
\end{abstract}

Keywords: COVID-19, IPA, online-based learning, Servqual

\begin{abstract}
Abstrak
Strategi belajar di rumah merupakan langkah kontrol yang berguna mengurangi penyebaran COVID-19 di kalangan siswa atau mahasiswa. Perubahan pembelajaran tatap muka menjadi pembelajaran online secara mendadak membuat pembelajaran tidak dapat berjalan dengan maksimal. Di masa pandemi COVID-19, Fakultas Teknik, Universitas Katolik Darma Cendika perlu melakukan pengukuran tingkat kepuasan mahasiswa terhadap pembelajaran online supaya kualitas layanan tetap terjaga. Tujuan penelitian ini adalah untuk mengukur tingkat kepuasan mahasiswa selama pembelajaran online di masa pandemi COVID-19 dengan menggunakan metode Service Quality (Servqual) dan Importance Performance Analysis (IPA). Servqual dan IPA merupakan metode untuk mengukur tingkat kepuasan dan kualitas suatu layanan. Hasil pengolahan Servqual menunjukkan bahwa seluruh 17 atribut yang diukur menghasilkan gap yang bernilai negatif. Hal ini menunjukkan ada kesenjangan antara persepsi dan harapan mahasiswa dalam pembelajaran online. Berdasarkan hasil matriks IPA, atribut dari pembelajaran online yang perlu diperbaiki secara prioritas adalah konsistensi dosen dalam memberikan kuliah secara baik, dosen handal dalam penggunaan platform pembelajaran, merespons dengan cepat dan efisien terkait kebutuhan mahasiswa dalam pembelajaran online, mendorong dan memotivasi mahasiswa untuk belajar dengan baik selama proses pembelajaran online, dan memahami kesulitan mahasiswa selama proses pembelajaran online.
\end{abstract}

Kata kunci: COVID-19, IPA, pembelajaran online, Servqual 


\section{Pendahuluan}

Coronavirus novel (COVID-2019) merupakan penyakit infeksi pneumonia akut (Bao et al., 2020). COVID-19 telah menyebar secara luas di dunia. Berdasarkan data World Health Organization (WHO) dan Public Health Emergency Operating Center (PHEOC) Kemenkes per tanggal 20 Juni 2020 sekitar 215 negara telah terinfeksi COVID-19, tidak terkecuali Indonesia. Sebagai upaya untuk mengurangi penyebaran COVID-19, seluruh negara di dunia berupaya menerapkan social distancing. Mudahnya COVID-19 menular antar manusia membuat banyak negara menutup kegiatan belajar mengajar di sekolah atau kampus. Menurut Viner et al. (2020), penutupan sekolah didasarkan pada bukti bahwa dengan mengurangi kontak fisik dan sosial antar siswa atau mahasiswa akan dapat mengurangi transmisi virus antar manusia dan mengurangi jumlah tenaga kesehatan yang merawat pasien. Penelitian terdahulu menyatakan bahwa penutupan sekolah efektif mengurangi puncak wabah influenza dengan rata-rata $29,7 \%$ dan menunda puncak dengan rata-rata 11 hari (Nafisah et al., 2018). Hal ini juga menjadi cara yang cukup efektif untuk mengurangi penyebaran COVID-19 di tingkat anak-anak dan remaja.

Saat ini Indonesia merupakan negara dengan kasus COVID-19 terbanyak di Asia Tenggara. Berdasarkan informasi Kementerian Kesehatan Republik Indonesia tanggal 20 Juni 2020, jumlah kasus terinfeksi COVID-19 di Indonesia mencapai 43.803 orang, jumlah kasus ini dapat terus meningkat. Sejak bulan Maret 2020 secara nasional kegiatan belajar mengajar siswa atau mahasiswa dilakukan di rumah. Strategi belajar di rumah merupakan langkah kontrol yang berguna dalam mengurangi respons infeksi siswa atau mahasiswa. Situasi yang tidak pernah terduga sebelumnya membuat setiap sekolah, orang tua, dan siswa atau mahasiswa mengupayakan untuk kegiatan belajar tetap berjalan meskipun melalui pembelajaran online. Perubahan pembelajaran tatap muka menjadi pembelajaran online secara mendadak membuat pembelajaran tidak dapat berjalan dengan maksimal. Banyak kendala dalam pembelajaran online yang sebelumnya tidak pernah dipersiapkan secara matang.
Berdasarkan observasi di lapangan, selama pembelajaran online di masa pandemi COVID19, banyak mahasiswa Fakultas Teknik, Universitas Katolik Darma Cendika mengeluhkan sistem pembelajaran online yang berlangsung. Industri jasa apabila tidak didukung dengan pelayanan yang tepat maka akan berakibat ketidak-puasan oleh konsumen. Oleh karena itu peningkatan kualitas pelayanan pendidikan, dalam hal ini pembelajaran online sangat diperlukan agar kepuasan mahasiswa terpenuhi. Jika kepuasan mahasiswa tidak terpenuhi maka mengakibatkan kejenuhan mahasiswa dalam mengikuti pembelajaran online, penurunan nilai mahasiswa, penurunan loyalitas mahasiswa, dan fakultas tidak dapat bersaing dengan kompetitor.

Pengukuran kepuasan konsumen dapat dilakukan melalui beberapa metode. Metodemetode yang biasanya digunakan untuk mengukur kepuasan pelayanan pendidikan adalah Quality Funciton Deployement atau QFD (Pramasatya et al., 2017), Kano (Wijaya \& Suwastika, 2017)., Topsis (Surya, 2018), dan Servqual (Nurdianti \& Suhendra, 2019). Servqual merupakan metode yang digunakan untuk mengukur kualitas layanan berdasarkan gap analysis yang menggambarkan perbedaan persepsi pelanggan dan harapan pelanggan terhadap pelayanan. Metode Servqual mampu mengidentifikasi tren kualitas dalam layanan, melalui survei berkala, yang bertujuan untuk mengevaluasi tingkat kepuasan pelanggan (Wagner et al., 2017). Servqual menjadi metode yang paling banyak digunakan untuk mengukur kualitas layanan, salah satunya adalah layanan pendidikan (Kamble \& Sarangdhar, 2015; Soares et al., 2017; Afridi et al., 2016; Suhendra \& Nurdianti, 2016; Sumarmi \& Wahyuni, 2016; Leonnard, 2018). Menurut Jabnoun \& Khalifa (2005), beberapa kelebihan Servqual adalah memiliki dimensi dan prosedur analisis yang sudah standar dalam menginterpretasikan hasil, telah terbukti keandalannya, dan valid dalam beberapa situasi jasa. Hal tersebut yang menjadi alasan pemilihan metode Servqual dalam penelitian ini.

Servqual hanya menganalisis tentang kesenjangan atau gap yang terjadi antara harapan mahasiswa dengan persepsi layanan, sedangkan dibutuhkan analisa tentang tingkat kepentingan variabel menurut mahasiswa 
terkait dengan kinerja pembelajaran online. Oleh karena itu dilakukan analisis tingkat kepentingan dengan menggunakan metode Importance Performance Analysis (IPA). Menurut Sever (2015), metode IPA merupakan alat yang berguna dalam menguji kepuasan pelanggan dan strategi manajemen. Metode IPA dianalisis melalui perhitungan tingkat kesesuaian dan matriks IPA. Analisis IPA menggambarkan atribut paling penting yang dirasakan oleh konsumen. Matriks IPA terdiri dari empat kuadran, yaitu kuadran I, kuadran II, kuadran III, dan kuadran IV. Metode IPA telah banyak digunakan di beberapa area layanan industri termasuk di dunia pendidikan (Lakkoju, 2016; McLeay et al., 2017; Bezuidenhout \& Jager, 2014; Luo et al., 2015).

Penelitian ini bertujuan untuk mengukur tingkat kepuasan mahasiswa selama pembelajaran online di masa pandemi COVID19 dengan menggunakan metode Servqual dan IPA. Hasil pengukuran ini diharapkan dapat menjadi dasar perbaikan dalam pembelajaran online supaya kualitas pelayanan dan kepuasan mahasiswa tetap terjaga di masa pandemi COVID-19.

\section{Metodologi}

Data yang digunakan dalam penelitian ini adalah data sekunder dan data primer. Data sekunder berasal dari studi literatur untuk menentukan atribut pada dimensi Servqual. Data primer berasal dari pengisian kuesioner. Kuesioner berisi atribut yang disesuaikan dengan kualitas pembelajaran online dengan merujuk lima dimensi Servqual. Total atribut yang digunakan adalah 17 atribut, dengan penilaian berdasarkan harapan responden dan persepsi layanan.

Skala pengukuran yang digunakan untuk penelitian ini adalah skala pengukuran likert dimulai dari angka 1 sampai 5 . Skala likert mampu mengukur sikap, pendapat dan persepsi seseorang atau sekelompok tentang kejadian atau gejala sosial.

Setelah data diisi oleh responden, selanjutnya data diuji validitas dan reliabilitas untuk memastikan data yang dikumpulkan layak digunakan. Pengolahan data dari uji validitas, reliabilitas, perhitungan gap analysis, tingkat kesesuaian, dan pembuatan matriks IPA menggunakan software SPSS. Uji validitas menggunakan rumus Bivariate Correlations.
Data dianggap valid apabila nilai $r_{\text {hitung }}$ lebih besar dari $r_{\text {tabel }}$ (person product moment). Pembacaan $r_{\text {tabel }}$ (person product moment) berdasarkan banyaknya sampel yang digunakan. Pengujian reliabilitas dengan menggunakan rumus Cronbach's Alpha. Menurut Priyatno (2010), data dinyatakan reliabel jika hasil dari Cronbach's Alpha lebih besar dari 0,7 .

Data yang diperoleh dari instrumen yang valid dan reliabel pada proses pengukuran kualitas dengan metode Servqual. Pada metode Servqual, dilakukan perhitungan gap antara rata-rata nilai harapan dengan rata-rata nilai persepsi layanan. Rumus untuk memperoleh rata-rata nilai harapan atau persepsi adalah membagi total nilai harapan atau persepsi dengan jumlah keseluruhan responden.

Untuk memetakan kategori dari atribut dimensi pembelajaran online diukur dengan tingkat kesesuaian dan matriks IPA, sehingga dapat diketahui prioritas peningkatan kualitas pembelajaran online. Data yang dibutuhkan pada perhitungan tingkat kesesuaian adalah skor harapan dan persepsi layanan dari setiap atribut. Rumus tingkat kesesuaian dapat dilihat pada Pers. 1 berikut ini.

$$
T k i=\frac{X i}{Y i} \times 100 \%
$$

Pers.1

Sebagai keterangan, Tki = tingkat kesesuaian responden, $\mathrm{Xi}=$ skor penilaian persepsi kinerja layanan, $\mathrm{Yi}=$ skor penilaian harapan responden. Data yang dibutuhkan pada pembuatan matriks IPA adalah rata-rata nilai setiap butir atribut, di bagian harapan ataupun persepsi layanan. Sumbu horizontal $(X)$ diisi oleh rata-rata nilai tingkat persepsi kinerja layanan, sedangkan sumbu vertikal $(Y)$ diisi oleh rata-rata nilai tingkat harapan.

Populasi dalam penelitian ini adalah mahasiswa Fakultas Teknik Universitas Katolik Darma Cendika Surabaya yang menjalani pembelajaran online. Jumlah mahasiswa Fakultas Teknik yang menjalankan pembelajaran online adalah 90 orang. Penentuan jumlah sampel menggunakan rumus Slovin yang dapat dilihat pada Pers. 2.

$$
n=\frac{N}{1+N\left(e^{2}\right)}
$$

Pers.2 
Sebagai keterangan, $\mathrm{n}=$ jumlah sampel, $\mathrm{N}=$ jumlah populasi, $e=$ toleransi terjadinya galat, taraf signifikansi $=0,05$. Setelah dihitung dengan rumus Slovin, dengan jumlah populasi sebanyak 90 orang maka jumlah sampel yang dihasilkan adalah 74 orang. Responden dipilih secara purposive sampling. Responden yang layak mengisi kuesioner merupakan mahasiswa aktif yang menjalankan pembelajaran online selama pandemi COVID19.

\section{Hasil dan Diskusi}

\section{Pengumpulan Data}

Penelitian ini menggunakan lima dimensi Servqual, yaitu: Tangible, Realibility, Responsiveness, Assurance, dan Emphaty. Pemilihan atribut pada setiap dimensi berasal dari penelitian Uppal et al. (2017), Caicedo et al. (2018), dan Stodnick (2008). Instrumen asli yang digunakan untuk menangkap faktor Servqual pada penelitian Uppal et al. (2017), Caicedo et al. (2018), dan Stodnick (2008) telah digunakan secara luas dalam penelitian sebelumnya.

Pertanyaan Uppal et al. (2017) yang digunakan dalam penelitian ini hanya 4 pertanyaan, terdapat pada dimensi emphaty. Pertanyaan Caicedo et al. (2018) yang digunakan dalam penelitian ini sebanyak 6 pertanyaan, yaitu pertanyaan pada dimensi tangible dan reliability. Pertanyaan Stodnick (2008) yang digunakan dalam penelitian ini sebanyak 7 pertanyaan yang terdapat pada dimensi responsiveness dan assurance. Pertanyaan-pertanyaan tersebut diubah secara kontekstual untuk memastikan kesesuaian dalam konteks pembelajaran online. Total atribut yang digunakan dalam penelitian ini sebanyak 17 atribut. Atribut setiap dimensi Servqual tersaji pada Tabel 1.

Atribut pada Tabel 1 dinilai oleh mahasiswa dengan menggunakan skala likert. Skala likert yang digunakan untuk mengukur tingkat harapan dan persepsi layanan pembelajaran online dikelompokkan menjadi 5 kategori yaitu sangat tidak penting, tidak penting, cukup penting, penting, dan sangat penting. Dari penilaian tersebut maka diperoleh perbandingan nilai harapan mahasiswa dengan persepsi layanan pembelajaran online.
Tabel 1. Atribut setiap 5 dimensi Servqual

\begin{tabular}{|c|c|}
\hline Kode & Tangible \\
\hline P1 & $\begin{array}{l}\text { Penggunaan alat bantu interaktif untuk } \\
\text { pembelajaran online }\end{array}$ \\
\hline $\mathrm{P} 2$ & $\begin{array}{l}\text { Kemudahan akses dan koneksi platform } \\
\text { pembelajaran online }\end{array}$ \\
\hline P3 & $\begin{array}{l}\text { Pemilihan platform pembelajaran online yang } \\
\text { bervariatif }\end{array}$ \\
\hline Kode & Reliability \\
\hline P4 & $\begin{array}{l}\text { Konsistensi dosen memberikan kuliah dengan } \\
\text { baik }\end{array}$ \\
\hline P5 & $\begin{array}{l}\text { Dosen handal dalam mengelola kelas saat } \\
\text { pembelajaran onlilne }\end{array}$ \\
\hline P6 & $\begin{array}{l}\text { Dosen handal dalam penggunaan platform } \\
\text { pembelajaran online }\end{array}$ \\
\hline Kode & Responsiveness \\
\hline P7 & $\begin{array}{l}\text { Dosen merespon dengan cepat dan efisien } \\
\text { tentang kebutuhan mahasiswa selama belajar } \\
\text { online }\end{array}$ \\
\hline P8 & $\begin{array}{l}\text { Dosen mampu beradaptasi dari pembelajaran } \\
\text { konvensional ke pembelajaran online }\end{array}$ \\
\hline P9 & $\begin{array}{l}\text { Dosen menyambut pertanyaan dan komentar } \\
\text { mahasiswa }\end{array}$ \\
\hline Kode & Assurance \\
\hline $\mathrm{P} 10$ & Dosen mengajar sesuai bidangnya \\
\hline P11 & $\begin{array}{l}\text { Dosen bersikap adil dan tidak memihak dalam } \\
\text { penilaian }\end{array}$ \\
\hline P12 & Dosen menjawab pertanyaan mahasiswa \\
\hline P13 & Dosen menguasai materi yang diajarkan \\
\hline Kode & Emphaty \\
\hline P14 & $\begin{array}{l}\text { Dosen mendorong dan memotivasi } \\
\text { mahasiswa melakukan pembelajaran terbaik } \\
\text { dalam proses pembelajaran online }\end{array}$ \\
\hline P15 & $\begin{array}{l}\text { Dosen memahami kesulitan mahasiswa } \\
\text { dalam proses pembelajaran online }\end{array}$ \\
\hline P16 & $\begin{array}{l}\text { Dosen perhatian dengan mahasiswa selama } \\
\text { pembelajaran online }\end{array}$ \\
\hline P17 & $\begin{array}{l}\text { Dosen menanamkan minat jangka panjang } \\
\text { untuk mahasiswa tetap bertahan dalam } \\
\text { proses pembelajaran online }\end{array}$ \\
\hline
\end{tabular}

\section{Uji Validitas dan Reliabilitas}

Menurut Sugiyono (2016), uji validitas menunjukkan derajat ketepatan antara data sesungguhnya yang terjadi pada objek dengan data yang dikumpulkan oleh peneliti. Secara teori pengujian validitas dilakukan kepada 30 responden, sebagai syarat minimal untuk uji validitas. Hasil uji validitas di awal penyebaran kuesioner dengan jumlah 30 responden adalah valid. Selanjutnya kuesioner diisi oleh 74 responden dan kembali diuji nilai validitasnya. Nilai validitas diukur dengan membandingkan nilai rhitung dengan rtabel. Berdasarkan Tabel $r$ (person product moment) uji 2 sisi pada taraf signifikansi 0,05 dan sampel sebanyak 74 orang maka nilai $r_{\text {tabel }}$ adalah 0,229 . Jika nilai $r_{\text {hitung }}$ lebih besar dari $r_{\text {tabel }}$ maka data dinyatakan valid, begitu pun sebaliknya jika 


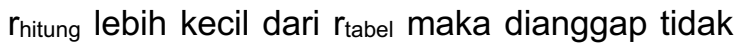
valid. Hasil uji validitas dari seluruh data harapan mahasiswa dan persepsi layanan menunjukkan $r_{\text {hitung }}$ lebih besar dari $r_{\text {tabel, }}$ sehingga keseluruhan data dinyatakan valid. Hasil uji validitas 74 responden disajikan pada Tabel 2.

Tabel 2. Uji validitas data tingkat kepuasan dan tingkat kepentingan pembelajaran online

\begin{tabular}{|c|c|c|}
\hline \multirow{2}{*}{ Kode } & Tingkat Kepentingan & Tingkat Kepuasan \\
\cline { 2 - 3 } & Total correlation & Total correlation \\
\hline P1 & 0,439 & 0,423 \\
\hline P2 & 0,547 & 0,651 \\
\hline P3 & 0,387 & 0,580 \\
\hline P4 & 0,599 & 0,625 \\
\hline P5 & 0,500 & 0,702 \\
\hline P6 & 0,598 & 0,765 \\
\hline P7 & 0,682 & 0,814 \\
\hline P8 & 0,675 & 0,744 \\
\hline P9 & 0,759 & 0,755 \\
\hline P10 & 0,724 & 0,728 \\
\hline P11 & 0,766 & 0,734 \\
\hline P12 & 0,765 & 0,751 \\
\hline P13 & 0,740 & 0,602 \\
\hline P14 & 0,724 & 0,669 \\
\hline P15 & 0,786 & 0,781 \\
\hline P16 & 0,708 & 0,723 \\
\hline P17 & 0,401 & 0,667 \\
\hline
\end{tabular}

Uji reliabilitas menunjukkan kestabilan dari setiap atribut yang diukur sehingga data terbebas dari variansi kesalahan acak. Nilai reliabilitas menggunakan perhitungan Cronbach's Alpha. Nilai Cronbach's Alpha dari penilaian harapan mahasiswa adalah 0,753 dan nilai Cronbach's Alpha dari penilaian persepsi layanan pembelajaran online adalah 0,761 . Dari hasil tersebut menyatakan bahwa atribut yang telah diisi oleh mahasiswa adalah reliabel karena lebih dari 0,7.

\section{Pengukuran Kualita Layanan}

Pengukuran nilai kualitas layanan dengan Servqual diperoleh dengan menghitung selisih antara rata-rata nilai persepsi layanan dan rata-rata nilai harapan mahasiswa terhadap pembelajaran online. Jika gap bernilai negatif maka terdapat kesenjangan antara harapan dan persepsi, sebaliknya jika nilai gap positif menunjukkan kualitas pelayanan melebihi tingkat kepuasan mahasiswa.

Rata-rata nilai persepsi kinerja, harapan mahasiswa, dan gap masing-masing atribut tersaji pada Tabel 3.
Tabel 3. Perhitungan nilai gap setiap atribut

\begin{tabular}{|c|c|c|c|}
\hline Kode & $\begin{array}{c}\text { Rata-rata } \\
\text { Nilai Persepsi }\end{array}$ & $\begin{array}{c}\text { Rata-rata } \\
\text { Nilai } \\
\text { Harapan }\end{array}$ & Gap \\
\hline P1 & 3,568 & 4,23 & $-0,662$ \\
\hline P2 & 3,189 & 4,243 & $-1,054$ \\
\hline P3 & 3,5 & 3,608 & $-0,108$ \\
\hline P4 & 3,405 & 4,514 & $-1,109$ \\
\hline P5 & 3,445 & 4,324 & $-0,879$ \\
\hline P6 & 3,568 & 4,365 & $-0,797$ \\
\hline P7 & 3,5 & 4,446 & $-0,946$ \\
\hline P8 & 3,486 & 4,284 & $-0,798$ \\
\hline P9 & 3,973 & 4,5 & $-0,527$ \\
\hline P10 & 4,040 & 4,419 & $-0,379$ \\
\hline P11 & 3,689 & 4,662 & $-0,973$ \\
\hline P12 & 4,125 & 4,540 & $-0,415$ \\
\hline P13 & 3,973 & 4,514 & $-0,541$ \\
\hline P14 & 3,486 & 4,405 & $-0,919$ \\
\hline P15 & 3,338 & 4,5 & $-1,162$ \\
\hline P16 & 3,486 & 4,311 & $-0,825$ \\
\hline P17 & 3,216 & 4,108 & $-0,892$ \\
\hline
\end{tabular}

Keseluruhan nilai gap pada 17 atribut bernilai negatif. Hal ini menunjukkan ada kesenjangan antara persepsi layanan dan harapan mahasiswa dalam pembelajaran online.

\section{Analisis Prioritas Perbaikan}

Prioritas perbaikan disusun dengan menggunakan metode IPA. Pada metode ini terdapat perhitungan untuk menentukan urutan perbaikan layanan, diukur dengan tingkat kesesuaian dan matriks IPA. Tingkat kesesuaian merupakan persentase dari perbandingan total skor persepsi kinerja layanan terhadap total skor harapan dan tiap atribut. Hasil tingkat kesesuaian seluruh atribut disajikan pada Tabel 4.

Tabel 4. Tingkat kesesuaian setiap atribut

\begin{tabular}{|c|c|c|c|}
\hline Kode & Persepsi & Harapan & $\begin{array}{c}\text { Tingkat } \\
\text { kesesuaian (\%) }\end{array}$ \\
\hline P1 & 264 & 313 & 84,34 \\
\hline P2 & 236 & 314 & 75,16 \\
\hline P3 & 259 & 267 & 97 \\
\hline P4 & 252 & 334 & 75,45 \\
\hline P5 & 255 & 320 & 79,69 \\
\hline P6 & 264 & 323 & 81,73 \\
\hline P7 & 259 & 329 & 78,72 \\
\hline P8 & 258 & 317 & 81,39 \\
\hline P9 & 294 & 333 & 88,29 \\
\hline P10 & 299 & 327 & 91,44 \\
\hline P11 & 273 & 345 & 79,13 \\
\hline P12 & 305 & 336 & 90,77 \\
\hline P13 & 294 & 334 & 88,02 \\
\hline P14 & 258 & 326 & 79,14 \\
\hline P15 & 247 & 333 & 74,17 \\
\hline P16 & 258 & 319 & 80,88 \\
\hline P17 & 238 & 304 & 78,29 \\
\hline & Rata-rata & 82,57 \\
\hline
\end{tabular}


Pengambilan keputusan diambil dengan membandingkan rata-rata tingkat kesesuaian dengan tingkat kesesuaian setiap atribut. Jika nilai tingkat kesesuaian setiap atribut lebih kecil dari rata-rata tingkat kesesuaian $(82,57 \%)$ maka atribut tersebut perlu perbaikan, dan bila tingkat kesesuaian setiap atribut lebih besar dari $82,57 \%$ maka atribut tersebut perlu dipertahankan. Atribut yang perlu dilakukan perbaikan adalah atribut $\mathrm{P} 2, \mathrm{P} 4, \mathrm{P} 5, \mathrm{P} 6, \mathrm{P} 7$, P8, P11, P14, P15, P16, dan P17.

Untuk mengetahui atribut yang paling berpengaruh pada kepuasan mahasiswa dan menjadi prioritas perbaikan maka perlu dilakukan analisis dengan menggunakan matriks IPA. Matriks ini disajikan melalui diagram kartesian yang sering disebut matriks IPA. Matriks IPA terdiri dari 4 kuadran yaitu kuadran prioritas utama, pertahankan prestasi, prioritas rendah, dan berlebihan. Dalam memetakan data ke diagram kartesius diperlukan nilai rata-rata setiap atribut yaitu rata-rata nilai persepsi kinerja layanan $(X)$ dan rata-rata nilai harapan mahasiswa $(Y)$, dimana nilai perhitungannya telah diperoleh pada Tabel 3. Hasil matriks IPA pada penelitian ini disajikan pada Gambar 1.

Berdasarkan matriks IPA diperoleh informasi bahwa pada kuadran I (prioritas utama) menggambarkan harapan tinggi namun persepsi rendah. Atribut yang masuk dalam kuadran I atau yang dianggap mahasiswa belum memuaskan ketika pembelajaran online diterapkan adalah atribut konsistensi dosen saat memberikan kuliah, keandalan dosen dalam penggunaan platform pembelajaran online, kecepatan, dan efisiensi dosen tentang kebutuhan selama belajar online, dorongan dan motivasi dosen terhadap mahasiswa untuk belajar dengan baik di masa pembelajaran online, dan pemahaman dosen terhadap kesulitan mahasiswa saat pembelajaran online.

Berdasarkan hasil observasi di lapangan, pembelajaran online selama pandemi COVID19 memberikan perubahan yang mendadak. Kegiatan pembelajaran yang seharusnya tetap dilaksanakan sesuai jadwal perkuliahan sering kali diubah berdasarkan kondisi dosen atau mahasiswa karena menganggap pembelajaran online dapat dilaksanakan kapan pun tanpa terbatas waktu, tempat, dan kondisi. Dosen yang sebelumnya belum pernah melakukan pembelajaran online secara terpaksa harus mengubah cara belajar konvensional menjadi pembelajaran online. Pemahaman terhadap pengoperasian platform pembelajaran online tentunya membutuhkan waktu untuk belajar. Waktu untuk memahami platform pembelajaran, perubahan situasi dan kondisi sering kali membuat dosen hanya berorientasi terhadap keberhasilan penyampaian materi. Hal ini menyebabkan dosen tidak sadar akan kesulitan yang dirasakan mahasiswa akibat perubahan pembelajaran dan kebutuhan motivasi dari dosen supaya mahasiswa tetap mengikuti pembelajaran dengan baik.

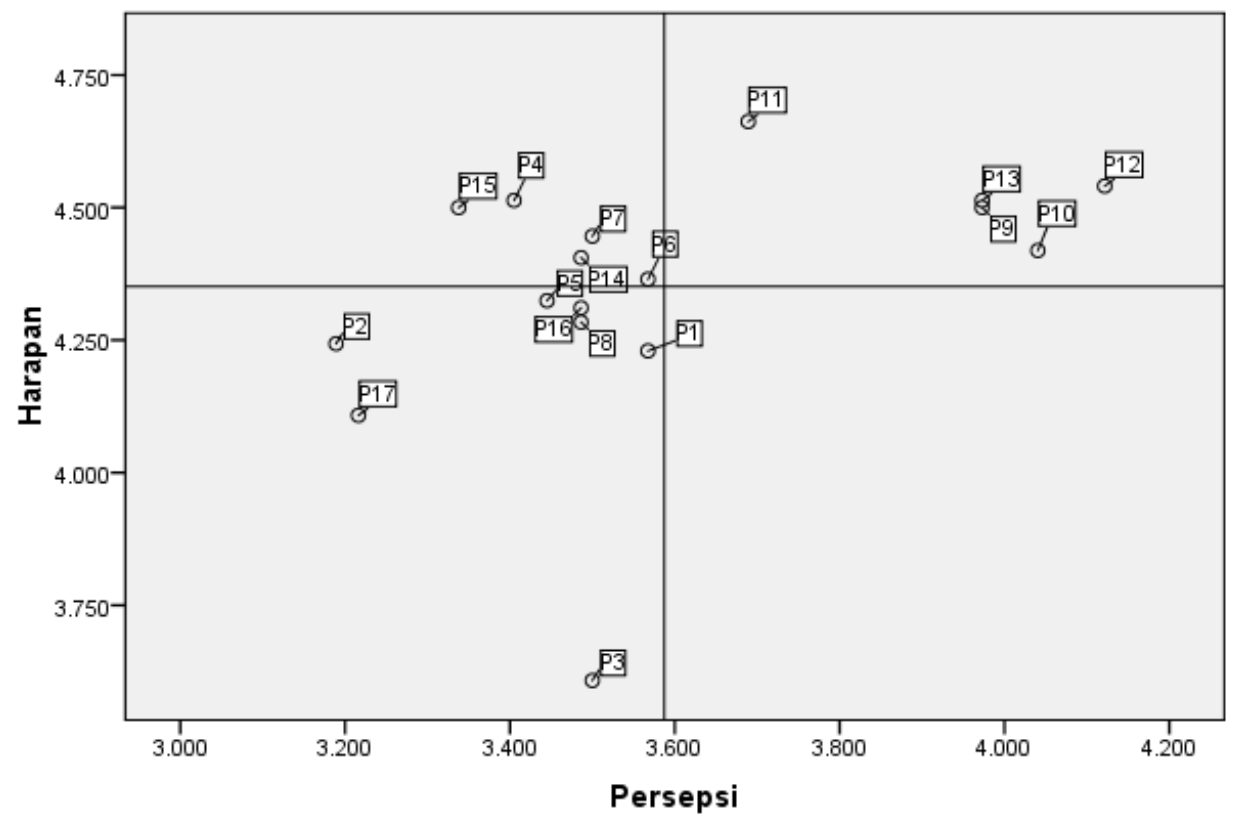

Gambar 1. Diagram kartesius pembelajaran online 
Pada kuadran II (pertahankan prestasi), atribut-atribut yang masuk dalam kuadran II atau memiliki harapan tinggi dan persepsi tinggi adalah dosen menyambut pertanyaan dan komentar mahasiswa, mengajar sesuai bidangnya, bersikap adil dan tidak memihak dalam penilaian, bersedia menjawab pertanyaan mahasiswa, dan menguasai materi yang dijelaskan. Hal ini berarti atribut-atribut pada kuadran II telah berhasil dilaksanakan dan dianggap sangat memuaskan oleh mahasiswa, untuk itu wajib dipertahankan.

Pada kuadran III (prioritas rendah) mendeskripsikan beberapa faktor yang kurang penting dan kurang memuaskan pengaruhnya bagi pelanggan. Pelaksanaannya oleh perusahaan biasa-biasa saja. Atribut yang masuk pada kuadran III adalah penggunaan alat bantu interaktif, kemudahan akses dan koneksi platform pembelajaran, pemilihan platform pembelajaran yang bervariatif, dosen andal mengelola kelas, dosen perhatian dengan mahasiswa, dan dosen menanamkan minat jangka panjang untuk mahasiswa bertahan dengan pembelajaran online selama COVID-19.

Berdasarkan hasil pengamatan, Fakultas Teknik Universitas Katolik Darma Cendika memberikan kebebasan oleh mahasiswa untuk menentukan platform pembelajaran online dengan persetujuan dosen pengampu mata kuliah. Selain itu beberapa dosen berupaya menggunakan alat bantu interaktif selama proses pembelajaran yaitu lewat penggunaan video pembelajaran yang dibagikan saat pembelajaran online berlangsung. Tidak terdapat pengelompokan pada kuadran IV (berlebihan). Hal ini berarti pembelajaran online belum melebihi harapan mahasiswa.

Berdasarkan pengelompokan pada matriks IPA, atribut dari pembelajaran online yang perlu diperbaiki secara prioritas oleh Fakultas Teknik, Universitas Katolik Darma Cendika adalah atribut pada kuadran I, yaitu konsistensi dosen dalam memberikan kuliah secara baik, dosen andal dalam penggunaan platform pembelajaran, dosen merespons dengan cepat dan efisien terkait kebutuhan mahasiswa dalam pembelajaran online, dosen mendorong dan memotivasi mahasiswa untuk belajar dengan baik, dan dosen memahami kesulitan mahasiswa selama proses pembelajaran online. Semakin sedikit atribut layanan yang masuk pada kuadran I maka semakin banyak atribut layanan yang mempunyai persepsi memuaskan dari mahasiswa. Dalam memperbaiki pembelajaran online diperlukan perbaikan secara berkelanjutan dan menyeluruh dari seluruh dosen di Fakultas Teknik, Universitas Katolik Darma Cendika.

Pembelajaran online menjadi cara utama proses belajar mengajar dapat terus berlangsung jika pandemi COVID-19 belum berlalu. Oleh sebab itu kepuasan mahasiswa Teknik Universitas Katolik Darma Cendika dapat ditingkatkan dengan meningkatkan kualitas pelayanan melalui perbaikan proses pembelajaran online. Semakin meningkat kualitas pelayanan mengakibatkan kepuasan siswa meningkat terhadap kualitas layanan (Chandra et al., 2018). Selain itu meningkatkan kepuasan melalui kualitas layanan yang baik akan berdampak pada loyalitas siswa (Chen, 2016). Secara tidak langsung loyalitas mahasiswa akan berpengaruh pada jumlah mahasiswa yang terdaftar di perguruan tinggi.

\section{Kesimpulan}

Hasil pengolahan Servqual menunjukkan bahwa seluruh 17 atribut yang diukur menghasilkan gap yang bernilai negatif. Hal ini menunjukkan ada kesenjangan antara persepsi dan harapan mahasiswa dalam pembelajaran online.

Berdasarkan hasil matriks IPA, atribut dari pembelajaran online yang perlu diperbaiki secara prioritas adalah konsistensi dosen dalam memberikan kuliah secara baik, andal dalam penggunaan platform pembelajaran, merespons dengan cepat dan efisien terkait kebutuhan mahasiswa dalam pembelajaran online, mendorong dan memotivasi mahasiswa untuk belajar dengan baik selama proses pembelajaran online, dan memahami kesulitan mahasiswa selama proses pembelajaran online.

\section{Daftar Pustaka}

Afridi, S.A., Khattak, A., \& Khan, A. (2016). Measurement of Service Quality Gap in The Selected Private Universities/Institutes of Peshawar Using Servqual Model. City University Research Journal , 6(1), 61-69.

Bao, Y., Sun, Y., Meng, S., Shi, J., \& Lu, L. (2020). 2019-nCoV Epidemic: Address Mental Health Care to Empower Society. Lancet, 395(10224), E37-E38. 
Bezuidenhout, G., \& Jager, J.D. (2014). Customer Satisfaction at Private Higher Education Institutions in South Africa: An Importance-Performance Analysis. Journal of Contemporary Management, 11(1), 206229.

Caicedo, J. E. Q., Berrio, S. P. R., \& Pinzón, O. J. R. (2018). Service Quality for Continuing Higher Education in Online Learning Environments. Entramado, 14(2), 22-34.

Chandra, T., Ng, M., \& Chandra, S. P. (2018). The Effect of Service Quality on Student Satisfaction and Student Loyalty : An Empirical Study. Journal of Social Studies Education Research, 9(3), 109-131.

Chen, Y. (2016). An Empirical Study on the Student Experience of Higher Education Service Quality in Taiwan. International Journal of Management Sciences, 6(12), 582-594.

Jabnoun, N., \& Khalifa, A. (2005). A Customized Measure of Service Quality in The UAE. Managing Service Quality, 15(4), 374-388.

Kamble, A.A., \& Sarangdhar, P. (2015). Assessing Service Quality and Customer Satisfaction in Management Education Using SERVQUAL Model. Journal of Commerce \& Management Thought, 6(2), 369-382.

Kementerian Kesehatan Republik Indoonesia, Situasi Terkini Perkembangan Coronavirus Disease (COVID-19) 21 Juni 2020, [Online], Diakses dari: https://covid19.kemkes.go.id/category/situa si-infeksi-emerging/info-coronavirus/\#.Xu8zEMQzblU [2020, 21 Juni].

Lakkoju, S. (2016). Importance-Performance Analysis of Service Quality in Higher Education: a Case Study. The Indian Journal of Industrial Relations, 52(1), 144156.

Leonnard. (2018). The Performance of Servqual to Measure Service Quality In Private University. ERIES Journal, 11(1), 16-21.

Luo, C., Gao, H., Gao, C., \& Ma, W. (2015). An Importance-Performance Analysis of EService Quality. International Conference on Logistics, Informatics and Service Sciences (LISS), 1-6.

McLeay, F., Robson, A., \& Yusoff, M. (2017). New Applications for Importance-
Performance Analysis (IPA) in Higher Education: Understanding Student Satisfaction. Journal of Management Development, 36(6), 780-800.

Nurdianti, R. R. S., \& Suhendra, S. (2019). Analisis Kepuasan Mahasiswa Melalui Metode Service Quality (Servqual) Pada Jurusan Pendidikan Ekonomi Universitas Siliwangi. Jurnal Siliwangi: Seri Pendidikan, 5(1), 47-51.

Pramasatya, A. G., Wulandari, S., \& Tripiawan, W. (2017). Peningkatan Kualitas Layanan Pendidikan Pada TK Sandhy Putra Menggunakan Metode QFD. e-Proceeding of Engineering, 4(3), 4278-4285.

Priyatno, D. (2010). Paham Analisa Statistik Data Dengan SPSS. YogyakartaL Mediakom.

Nafisah, S. B., Alamery, A. H., Nafesa, A. A., Aleid, B., \& Brazanji, N. A. (2018). School Closure During Novel Influenza: A Systematic Review. Journal of Infection and Public Health, 11(5), 657-661.

Sever. (2015). Importance-Performance Analysis: A Valid Management Tool?. Tourism Management, 48, 43-53.

Soares, M.C., Novaski, O., \& Anholon, R. (2017). Servqual Model Applied to Higher Education Public Administrative Services. Brazilian Journal of Operations \& Production Management, 14(3), 338-349.

Stodnick, M., \& Rogers, P. (2008). Using SERVQUAL to Measure the Quality of the Classroom Experience. Journal of Innovative Education, 6(1), 115-133.

Sugiyono. (2016). Metode Penelitian Kuantitatif, Kualitatif dan R\&D. Bandung: Alfabeta.

Suhendra, S., \& Nurdianti, R. R. S. (2018). Penggunaan Metode Servqual Dalam Pengukuran Kualitas Layanan Pendidikan. Indonesian Journal of Primary Education, 2(2), 71-75.

Sumarmi, W., \& Wahyuni, H.C. (2016). Analisa Tingkat Kepuasan Kualitas Layanan Perguruan Tinggi Swasta Berdasarkan Metode SERVQUAL. Jurnal Teknologi dan Manajemen Industri , 2(1), 15-20.

Surya, C. (2018). Penilaian Kinerja Dosen Menggunakan Metode TOPSIS (Studi Kasus: AMIK Mitra Gama). Rekayasa Sistem dan Teknologi Informasi, 2 (1), 322329. 
Uppal, M. A., Ali, S., \& Gulliver, S. R. (2017). Factors Determining E-Learning Service Quality. British Journal of Educational Technology, 49(3), 412-426.

Viner, R., Russell, S. M., Croker, H., Packer, J., Ward, J., Stansfield, C., ..., \& Booy, R. (2020). School Closure and Management Practices During Coronavirus Outbreaks Including COVID-19: A Rapid Systematic Review. The Lancet Child \& Adolescent Health, 4(5), P397-404.
Wagner, A., Merino, E.A.D., Martinelli, M., Polacinski, E., Wegner, R.S., \& Godoy, L.P. (2017). The Quality of Services in a Higher Education Institution: An Evaluation for The Integration of AHP, Servqual and QFD Methods. Disciplinarum Scientia, 12(1), 109-129.

Wijaya, I. G. N. S., \& Suwastika, I. W. K. (2017). Analisis Kepuasan Pengguna ELearning Menggunakan Metode Kano. Jurnal Sistem Dan Informatika, L-2, 128138. 
DOI: https://doi.org/10.26593/irsi.v9i2.4014.135-144

Halaman ini sengaja dikosongkan.

This page is intentionally left blank. 